\title{
Venture Capital and Financial Reporting in Newly Public Firms
}

\author{
Lars Helge Hass \\ Lancaster University Management School \\ 1.h.hass@lancaster.ac.uk \\ Monika Tarsalewska \\ University of Exeter Business School \\ m.tarsalewska@exeter.ac.uk
}

December 23, 2016

\begin{abstract}
When newly public firms emerge from relative obscurity, the quality of their financial reporting is often questioned by investors. However, the determinants of financial reporting quality in newly public firms are still largely unexplored. It is often assumed these firms resemble each other, but they actually differ quite dramatically in terms of the financing they receive before going public. Financial intermediaries such as venture capitalists (VCs) not only provide financing, they also play an active role in firm governance and in financial practices before the firm goes public. Venture capitalists are actively engaged in monitoring and advising their portfolio firms. Thus, we also expect them to exert significant influence over the development of financial reporting practices. This chapter reviews recent literature and empirical evidence on VCs and financial reporting quality in newly public firms. We survey the role of VCs in such activities as earnings management. In particular, we discuss how their monitoring activities and reputation can impact how their portfolio firms establish financial reporting practices. Subsequently, we also review the consequences of misreporting, and whether they affect VC behavior ex ante. Finally, we use recent data to provide empirical evidence on the effect of VCs on accrual and real earnings management.
\end{abstract}

Keywords: newly public firms, venture capital, earnings management 


\section{Introduction}

The transition from private to public ownership at the time of an initial public offering (IPO) has far-reaching consequences. For example, newly public firms must face increased scrutiny from investors and analysts, as well as a substantial increase in financial reporting requirements. Although these firms face similar public market pressures at the time of an IPO, there are significant differences during the pre-IPO period that can affect their post-IPO behavior. During a firm's development entrepreneurs and owners often develop very different governance mechanisms and financial reporting practices, which can have long-term effects even after a firm becomes listed on a stock exchange.

Theories about the separation of ownership and control assume that firms at the time of an IPO are basically similar in terms of governance mechanisms (Jensen and Meckling, 1976; Grossman and Hart, 1988; Zingales, 1995). However, these theories ignore the role that financial intermediaries such as venture capitalists (VCs), investment banks, and others play in establishing firm governance, reporting, and control structures.

VCs can play a significant role in reducing the agency costs between investors and firms (Gompers and Lerner, 2001). They also provide advice and act as monitors (Gompers, 1995; Lerner, 1995; Beuselinck and Manigart, 2007; Beuselinck et al., 2008; Nahata, 2008; Nahata et al., 2014; Ritter, 2015). However, as the providers of capital to entrepreneurial companies, VCs need to rely heavily on the financial data provided by firm management. It is thus crucial that this information be of the highest quality in order to ensure prudent investing and financing decisions.

Financial reporting quality can be measured in many different ways. The most common measure is accrual earnings management, which Walker (2013) defines as: 
The use of managerial discretion over (within GAAP) accounting choices, earnings reporting choices, and real economic decisions to influence how underlying economic events are reflected in one or more measures of earnings.

Because VCs have such a strong influence on the governance, reporting, and control practices of their portfolio firms, one would expect to find higher-quality reporting in VCbacked firms, i.e., lower accrual earnings management, than in non-VC-backed firms. Morsfield and Tan (2006) show that VC-backed firms tend to exhibit lower earnings management in newly public firms due to their monitoring role, which would further explain superior post-IPO performance.

Lee and Masulis (2011) study the role of financial intermediaries such as VCs and investment banks (IBs). They find that only the more reputable VCs and IBs restrain earnings management in IPO firms.

Besides accrual earnings management, firms can also change real economic decisions to influence earnings. They can reduce discretionary spending, such as advertising and research and development (R\&D) expenses, to manage earnings numbers. This dimension of earnings management is called real earnings management, because it distorts real economic decisions. Roychowdhury (2006) defines it as:

\section{Management actions that deviate from normal business practices, undertaken with the primary objective of meeting certain earnings thresholds.}

These distortions have long-term negative effects on firm performance. Wongsunwai (2013) shows that VC-backed firms tend to exhibit lower earnings management through 
accruals manipulation and real activities. He also finds that VC-backed firms have lower rates of financial restatements.

Finally, financial reporting quality can also be measured through the quality of internal control mechanisms. Cumming et al. (2016) analyze disclosures of material weaknesses in internal control under the 2002 Sarbanes-Oxley Act (SOX). They find that VC-backed firms disclose fewer material weaknesses in internal control, and those disclosures are more informative to the public markets.

The remainder of this chapter is structured as follows. Section 2 provides an overview of the role VCs play in the financing of young companies. In section 3, we discuss measures and empirical evidence of financial reporting quality. Section 4 presents empirical evidence on the role of $\mathrm{VCs}$ in the earnings management behavior of firms around IPOs. Section 5 concludes, and we discuss future research in section 6.

\section{Venture capital}

\subsection{VC investors}

Venture capitalists are a special type of owners. Acting as financial intermediaries, they reduce the agency costs between investors and entrepreneurs (Gompers and Lerner, 2001). Typically organized as limited partnerships, they raise funds from limited partners such as pension funds, high net worth individuals, endowments, and banks. As general partners, VCs are in charge of investing the money raised into portfolio companies. Their main activities include identifying and screening investment opportunities, executing the chosen deals, monitoring and advising the portfolio companies, and managing exit strategies. The typical time span from fundraising through exit is four to ten years, and VCs usually charge limited partners for basic management and performance fees (for more details, see, for example, Phalippou et al., 2016).

\subsection{VCs' monitoring role}


In their role as general partners, VCs take charge of investing the money raised into their portfolio companies, and they are heavily involved in firm management as well. Gorman and Sahlman (1989) note that VCs tend to visit their portfolio firms regularly and hold frequent meetings with management. They also work closely with the entrepreneurs and negotiate complex contracts with the portfolio firms, relating to, e.g., the split of returns, the allocation of control rights, and liquidation events (Kaplan and Strömberg, 2003).

Kaplan and Strömberg (2003) analyze a sample of contracts between VCs and entrepreneurs, and show that the main mechanisms VCs use to ensure smooth cooperation with entrepreneurs are residual cash flow rights, board and voting rights, liquidation rights, and redemption rights. VCs typically get 55\% residual cash flow rights, and from $41 \%$ to $46 \%$ of board seats in normal and adverse states, respectively.

Although the sample used in Kaplan and Strömberg (2003) is relatively small, other literature also shows the importance of contract design in the effective monitoring of portfolio firms (Hsu, 2004; Masulis and Nahata, 2009). Caselli et al. (2013) argue that the negotiated contracts usually feature a company performance component. Also, Cumming and Johan (2013) show that the contracts between VCs and entrepreneurs often improve the transparency of information flow. Masulis and Nahata (2011) report that, at exit, the purchase price of companies being monitored by VCs is demonstrably higher.

Another method VCs use to manage their portfolio firm investments is to allocate promised funding over several stages. The frequency of refinancing usually varies from a few months to a few years. Gompers (1995) finds that the number of financing stages depends on the expected agency costs between the VCs and entrepreneurs. "Staging" the funding installments serves as a hedge to control risk and increase VCs' bargaining power.

\subsection{VCs and newly public firms}


Several papers have suggested that more than $50 \%$ of newly public firms are backed by VC investors (Wongsunwai, 2013). Previous literature has shown that VC-backed firms are more successful than non-VC-backed firms. They have better post-IPO performance, are more innovative, have better governance mechanisms, and are less susceptible to fraud.

Other studies highlight the role of reputation in VC performance. In particular, Nahata (2008) shows that firms backed by more reputable VCs exit through IPO or acquisition, are faster at accessing public markets, and are more productive overall. ${ }^{1}$ Krishnan et al. (2011) report that VC-backed firms have better post-IPO performance than non-VC-backed firms in terms of better return on assets (ROA), higher market-to-book (M/B) ratios, survival rates, returns, and lower research and development $(\mathrm{R} \& D)$ expenditures. In a similar vein, Nahata et al. (2014) report that VC backing positively affects both firm performance and survival.

Several studies show that VC-backed firms also have higher patent rates (Kortum and Lerner, 2000; Bernstein et al., 2016). In fact, Tian and Wang (2014) posit that VCs have a generally higher tolerance for failure and are therefore more willing to support risky and innovative activities.

Evidence suggests that VC-backed firms enjoy better governance mechanisms as well. VCs need to establish sound governance practices in order to effectively manage their portfolio firms. Kaplan and Strömberg $(2003,2004)$ find that preliminary governance structures are generally established just after the VC investment occurs. Hochberg (2012) shows that VCbacked firms have better governance (e.g., lower earnings management), react more positively to the adoption of shareholder agreements, and have more independent boards. Tian et al. (2015) find that VCs are monitored externally as well. They show that markets punish VC funds that are less efficient at preventing fraud in newly public firms.

\footnotetext{
${ }^{1}$ For a detailed discussion on the effect of VC reputation, see Krishnan and Masulis (2011).
} 
Overall, we conclude that VC-backed firms tend to be more successful than otherwise similar non-VC-backed firms. This success is presumably achieved through the thorough screening and monitoring activities that VCs implement in their portfolio firms. However, in order to monitor and screen effectively, portfolio firms must first have solid financial reporting and control practices in place.

\subsection{Why and when do newly public firms manage earnings?}

VC investors typically prefer IPOs as an exit strategy. They generally aim to exit their portfolio investments within a specific period of time, and return the realized capital or shares in the newly public firm to the limited partners. Because VC investors earn performance fees on those investments, their goal is usually to maximize the price of the firm. Moreover, although they can sell some shares at the time of the IPO, they typically offload most of their shares to the market after the lock-up period, which usually lasts for 180 days. Therefore, VC investors may allow for a temporary change in reporting quality just prior to their exit in order to shed positive light on the portfolio firm's financial prospects. This would have direct consequences for the profits of $\mathrm{VC}$ investors, as it allows them to report higher returns to limited partners.

\section{Financial reporting quality}

\subsection{Measures of financial reporting quality}

Financial reporting quality can be difficult to measure in practice. Previous literature has used earnings management measures as proxies for financial reporting quality. However, earnings management can be difficult to assess because it depends largely on managerial discretion and is not directly observable.

Jones (1991) and Kothari et al. (2005) propose several methods to proxy for earnings management based on, e.g., accruals. However, there are other methods firms can use that are not reflected in accruals. For example, firms can adjust real activities and assumptions, such as 
what discount rate they use to calculate pension obligations. While there are conceptual issues surrounding whether accruals are in fact a good measure of earnings management, some studies proxy for financial reporting quality using alternative measures. One broader measure of management practice is internal control quality, such as disclosures of material weaknesses in internal control that are mandated by law.

\subsection{Accruals-based measures}

Total accruals are the difference between income and cash flows during a specific period. Management has multiple options at its disposal to manipulate income through accounting policy choices. Although early studies used total accruals to proxy for earnings management, not all accruals are reflective of the potential to manipulate earnings. We distinguish here between non-discretionary (unmanaged) and discretionary (managed) accruals. Therefore, the key to detecting earnings management is to estimate discretionary accruals $\left(D A C C_{t}\right)$, that is, the difference between total $\left(A C C_{t}\right)$ and expected $\left(E\left[A C C_{t}\right]\right)$ accruals:

$$
D A C C_{t}=A C C_{t}-E\left[A C C_{t}\right]
$$

The methodology of calculating discretionary accruals varies from model to model. DeAngelo (1988) proposes using the difference between total accruals at time $t$ less the total accruals from the previous period as a measure of discretionary accruals. One drawback with this approach is that it assumes non-discretionary accruals are constant over time. Dechow et al. (1995) correct for this issue, and estimate discretionary accruals as the difference between total and average accruals for a particular sector. However, this approach assumes that other firms do not manage earnings.

Jones (1991) proposes a more sophisticated solution: a regression-based time series approach to estimating discretionary accruals. First, total accruals are modeled to estimate parameters $\beta_{1}$ and $\beta_{2}$, as follows:

$$
T A_{t-n}=\alpha+\beta_{1} \Delta R E V_{t-n}+\beta_{2} P P E_{t-n}+\varepsilon_{t-n}
$$


where $\triangle R E V$ are changes in revenue, and $P P E$ is investment in properties, plant, and equipment. Second, discretionary accruals are estimated as total accruals less estimated accruals, where estimated accruals are calculated using the parameters from the first regression:

$$
D A C C_{t}=T A_{t}-\left(\tilde{\alpha}+\tilde{\beta}_{1} \Delta R E V_{t}+\tilde{\beta}_{2} P P E_{t}\right)
$$

Due to significant restrictions on the sample in the time series, however, DeFond and Jiambalvo (1994) propose a cross-sectional model, where total accruals are again estimated for each industry-year pair based on two-digit SIC codes:

$$
T A_{i, t-n}=\alpha+\beta_{1} \Delta R E V i_{i, t-n}+\beta_{2} P P E_{i, t-n}+\varepsilon_{t-n}
$$

Discretionary accruals are then estimated as total accruals less estimated accruals:

$$
D A C C_{t}=T A_{t}-\left(\tilde{\alpha}+\tilde{\beta}_{1} \Delta R E V_{t}+\tilde{\beta}_{2} P P E_{t}\right)
$$

Multiple variations of the original Jones (1991) model have been put forth over time. For example, Kothari et al. (2005) extend Jones's (1991) model by including lagged returns on assets (ROA), and calculating total accruals as working capital accruals only.

\subsection{Real activities manipulation}

Managerial discretion can also take the form of real activities manipulation. In contrast to accruals-based manipulation, where managers exercise their discretion based on various accounting choices, real activities manipulation involves changes in normal operations with the explicit aim of misleading investors into believing that financial performance was achieved under normal conditions (Roychowdhury, 2006). While accruals-based manipulation does not typically involve changing operations, real activities manipulation does alter normal firm policies. It can thus take various forms, such as sales manipulation through increased discounts, and decreases in spending on research and development (R\&D) or advertising (Graham et al., 2005; Wongsunwai, 2013; Kothari et al., 2016). Several studies find that firms manipulate both accruals and real activities. For example, Cohen and Zarowin (2010) and Kothari et al. (2016) show that manipulations occur around seasoned equity offerings. 
In order to measure real earnings management effectively, we need to focus on strategies that influence various indicators. We follow Roychowdhury (2006), and calculate two metrics to capture the acceleration of price discounts or more lenient credit terms, the reporting of lower cost of goods sold (COGS) through increased production, and decreases in discretionary spending, such as advertising, R\&D, and SG\&A expenses.

We first model normal levels of cash flow from operations (CFO) per industry-year, and then calculate our real earnings management metric as the difference from normal levels. We model CFO for each industry-year pair as follows:

$$
\frac{\text { CFO }_{t}}{\text { Assets }_{t-1} i t}=k_{1} \frac{1}{\text { Assets }_{t-1}}+k_{2} \frac{\text { Sales }_{t}}{\text { Asset }_{t-1}}+k_{3} \frac{\Delta \text { Sales }_{t}}{\text { Asset }_{t-1}}+\varepsilon_{t}
$$

Abnormal CFO is then calculated as the difference from normal CFO using the estimated coefficients from (6).

We also follow Roychowdhury (2006) in modeling COGS, normal production costs (PROD), and discretionary expenses (DISX), as follows:

$$
\begin{aligned}
& \frac{\operatorname{CoGS}_{t}}{\text { Asset }_{t-1} i t}=k_{1} \frac{1}{\text { Assets }_{t-1}}+k_{2} \frac{\text { Sales }_{t}}{\text { Asset }_{t-1}}+\varepsilon_{t} \\
& \frac{\text { PROD }_{t}}{\text { Asset }_{t-1}{ }_{i t}}=k_{1} \frac{1}{\text { Asset }_{t-1}}+k_{2} \frac{\text { sales }_{t}}{\text { Assets }_{t-1}}+k_{2} \frac{\Delta \text { Sales }_{t}}{\text { Asset }_{t-1}}+k_{2} \frac{\Delta \text { Sales }_{t-1}}{\text { Asset }_{t-1}}+\varepsilon_{t} \\
& \frac{\text { DISX }_{t}}{\text { Assets }_{t-1} i t}=k_{1} \frac{1}{\text { Assets }_{t-1}}+k_{2} \frac{\text { Sales }_{t}}{\text { Asset }_{t-1}}+\varepsilon_{t}
\end{aligned}
$$

In order to capture real earnings management, we combine these three measures into two metrics, as per Zang (2006). For the first metric, we multiply abnormal discretionary expenses by -1 and add to abnormal production costs (REM1). For the second metric, we multiply abnormal cash flows from operations and abnormal discretionary expenses by -1 , and then aggregate the two variables into one metric (REM2). Overall, higher values for both metrics are correlated with higher levels of real earnings management.

\subsection{Evidence on earnings management}


We next focus on the empirical evidence on earnings management. Graham et al.'s (2005) survey based on interviews with U.S. managers indicates they perceive earnings as the most important financial metric, and will try to smooth earnings over time. As we noted earlier, earnings management can be difficult to detect, so studies have focused primarily on major corporate events such as 1) equity issues, 2) mergers and acquisitions, and 3) earnings games (Walker, 2013). We describe these three events in more detail next.

First, firms have incentives to overestimate earnings in expectation of an equity issue, whether it be an IPO or a SEO, because an overvaluation allows for a smooth wealth transfer from new to current shareholders. Several studies find that managers make income-increasing adjustments prior to IPOs (Teoh et al., 1998a, 1998c; DuCharme et al., 2004; Rangan, 1998; Cohen and Zarowin, 2010) and SEOs (Teoh et al., 1998b). However, Ball and Shivakumar (2008) find no evidence of earnings management before IPOs for a U.K. sample. Lo (2008) posits that it is difficult to reach a conclusion on this subject, while Fan (2007) finds it depends on ownership structure.

Second, firms may have incentives to misreport in anticipation of a merger or acquisition for reasons similar to those in the case of equity offerings. Early studies found that managers have little incentive to increase earnings before management buyouts (DeAngelo, 1988; Perry and Williams, 1994). However, firms using their own stock as a method of payment may opt to manage earnings upward in order to inflate the value of their payment currency before the acquisition (Erickson and Wang, 1999).

Anagnostopoulou and Tsekrekos (2015) find that target firms may also be engaged in earnings management. They identify a sample of targets that put themselves up for sale and then managed their earnings downward during the years surrounding the announcement year. They seemed to facilitate the completion of the deal at the cost of shareholders. 
Third, firms may have incentives to misreport if they engage in earnings games to meet analyst forecasts (Walker, 2013). Many firms intend to beat analysts' forecasts to send positive signals to the market. There is a large branch of literature illustrating how firms manage earnings before earnings disclosures in order to meet analyst forecasts (Abarbanell and Lehavy, 2003; Kasznik, 1999; Burgstahler and Eames, 2006). Also, evidence from U.K. managers suggests they engage in real earnings management (Choi et al., 2006).

Garcia-Osma and Young (2009) find that U.K. firms are more likely to cut R\&D expenditures in the financial year following a year that a firm failed to report positive earnings levels and changes. But the analysts and investors serve as external monitors, and it is not possible to detect the very opaque strategies used to manipulate earnings (Ball and Shivakumar, 2008).

\section{Evidence on $\mathrm{VC}$ and financial reporting quality}

\subsection{Sample selection and descriptive statistics}

Our sample includes all IPOs in the SDC Thomson One database from 1980 through 2015. We use the U.S. public marketplace, with "common shares" as the security type. Following prior studies, we exclude equity offerings of financial institutions (SIC codes between 6000 and 6999), real estate investment trusts (REITs), closed-end funds, spin-offs, former LBOs, and foreign firms, because their disclosure requirements differ strongly from those of other firms. We also only include issues with offer prices that are higher than $\$ 5$. We use Compustat to match financial data. Our final sample consists of 825 IPOs.

This sample size highlights the recent downward trend of U.S. listings compared to that of international listings (Doidge et al., 2016). Gao et al. (2013) posit that the recent drop in U.S IPO volume is caused by the economies of scope hypothesis. They posit that smaller firms are being acquired more rapidly by firms who desire fast growth as a means to maximize profits over a shorter time frame. We focus on the U.S., because previous research has demonstrated 
the impact of different institutional environments on financial market outcomes (Cumming and Johan, 2013). Concentrating on the U.S. also allows us to isolate the effect of VC backing on earnings management.

From the data, we can observe whether a company obtained VC backing. Our primary test variable is $\mathrm{VC}$, which equals 1 if the sample company was backed by a $\mathrm{VC}$ fund at the time of its IPO, and 0 otherwise.

We measure earnings management using several proxies. First, we calculate the measure of earnings management (DA) based on abnormal accruals by using a cross-sectional version of the Jones (1991) model, modified as in Dechow et al. (1995). Second, following Cohen and Zarowin (2010), we calculate two measures of real earnings management, REM1 and REM2.

We also include several control variables that have been linked to earnings management in prior studies: return on assets (ROA) to control for a firm's profitability and performance, the debt-to-equity ratio (leverage) to control for a firm's financial health, the book-to-market (BM) ratio to proxy for a firm's growth opportunities, and firm size (size). Finally, we control for firm growth (sales growth) because we expect rapid expansion to affect financial reporting quality. We also include industry and year fixed effects to control for macroeconomic shocks.

Table 1 gives the summary statistics for non-VC-backed firms (at the top), VC-backed firms (in the middle), and the full sample (at the bottom). Earnings management proxies (DA, REM1, and REM2) show that the mean is lower for VC-backed firms, suggesting those firms are less likely engage in managing reported earnings upward. In unreported t-tests, the difference in means between VC- and non-VC-backed firms is statistically significant. Summary statistics suggest that VC-backed firms have lower ROA, leverage, book to market, size, and sales growth. 
Table 2 shows the correlations between variables. We find that the correlations between accruals and real earnings management measures are positive but low. As expected, the correlation between the two real earnings management metrics is strongly positive.

[Please insert Tables 1 and 2 here]

\subsection{Results}

This subsection discusses the results from our regression analysis. Table 3 shows the effect of VC backing on the first measure of accrual-based earnings management (DA). All the tables show the results as follows: for the three years surrounding the IPO in model (1), the one year prior to the IPO in model (2), the one year after the IPO in model (3), and the two years after the IPO in model (4).

The results suggest a negative effect of VC backing overall on earnings management. However, this effect is driven by earnings management before the IPO, which suggests that VC-backed firms engage in significantly lower levels of accrual earnings management pre-IPO in order to protect the reputation of the VC. For the three years surrounding the IPO, VCbacked firms exhibit discretionary accruals of about $4 \%$ of total assets, which is less than comparable non-VC-backed firms. This effect increases to $9 \%$ if we focus on the year prior to the IPO. In contrast, post-IPO earnings management is not significantly different between VCand non-VC-backed companies.

[Please insert Table 3 here]

Table 4 shows results for the effect of VC backing on REM1, the first measure of real earnings management. A higher REM1 implies a higher likelihood that the firm is involved in 
upward earnings management by sales manipulation and/or decreases in discretionary expenditures as a means to temporarily increase earnings. The results show a negative and statistically significant effect of VC backing on real earnings management across all models. Moreover, the coefficient sizes are quite large, pointing to an economically significant effect.

[Please insert Table 4 here]

Table 5 gives results for the effect of VC backing on REM2, the second measure of earnings management. In a similar fashion, a higher REM2 implies a higher likelihood that the firm is involved in upward earnings management. The results again show a negative and statistically significant effect of VC backing on earnings management.

[Please insert Table 5 here]

\section{Conclusion}

This chapter reviews the role venture capitalists play in the financing of young companies. We find that VCs impact not only financing and investment decisions, but also the financial reporting structures of their portfolio firms. Financial reporting integrity is vital to investors, because it is the fundamental channel through which information is communicated. We find that VCs have a strong impact on the financial reporting decisions of their portfolio firms. Furthermore, we find that VC-backed firms tend to engage in less earnings management, both accrual-based and real. This effect is strongest for the period surrounding the IPO, when the VC is still invested in the company. Overall, our findings underline the strong impact of VCs on their portfolio firms' accounting choices.

\section{Future research}


Many studies have found evidence that IPO market-based reputation measures affect earnings management. However, none has yet explored the reporting quality of VC performance to their limited partners in-depth. Future research may want to control for VC heterogeneity in terms of how fund performance reporting behavior affects post-IPO reporting behavior. For example, Cumming and Walz (2010) use an international sample, and document that fund performance reporting behavior depends on a country's legal and accounting environment. And Johan and Zhang (2016) note that the reporting behavior of PE funds is correlated with a tendency to overstate performance reports. Therefore, it would be interesting to examine 1) how institutional and legal environments affect earnings management in newly public firms, and 2) how the tendency to report inflated valuations to limited partners affects subsequent valuations of newly public firms. 


\section{References}

Abarbanell, J., and Lehavy, R. (2003). Can stock recommendations predict earnings management and analysts' earnings forecast errors? Journal of Accounting Research, 41, 1-31.

Anagnostopoulou, S.C., and Tsekrekos, A.E. (2015). Earnings management in firms seeking to be acquired, British Accounting Review 47, 351-375.

Ball, R., and Shivakumar, L. (2008). Earnings quality at initial public offerings, Journal of Accounting and Economics 45, 324-349.

Bernstein, S., Giroud, X., and Townsend, R.R. (2016). The impact of venture capital monitoring, Journal of Finance 71, 1591-1622.

Beuselinck, C., Deloof, M., and Manigart, S. (2008). Private equity investments and disclosure policy, European Accounting Review 17, 607-639.

Beuselinck, C., and Manigart, S. (2007). Financial reporting quality in private equity backed companies: The impact of ownership concentration, Small Business Economics 29, 261-274.

Burgstahler, D., and Eames, M. (2006). Management of earnings and analysts' forecasts to achieve zero and small positive earnings surprises, Journal of Business Finance \& Accounting 33, 633-652.

Caselli, S., Garcia-Appendini, E., and Ippolito, F. (2013). Contracts and returns in private equity investments, Journal of Financial Intermediation 22, 201-217.

Choi, Y., Walker, M., and Young, S. (2006). Earnings reporting and analysts' earnings forecasts: The perceptions of UK analysts and financial managers, Manchester Business School, Working paper.

Cohen, D.A., and Zarowin, P. (2010). Accrual-based and real earnings management activities around seasoned equity offerings, Journal of Accounting and Economics 50, 2-19.

Cumming, D., Hass, L.H., Myers, L.A., and Tarsalewska, M. (2016). Venture Capital and the Disclosure of Material Weaknesses in Internal Control, Available at SSRN: http://ssrn.com/abstract=2640873.

Cumming, D., and Johan, S. (2013). Venture Capital and Private Equity Contracting: An International Perspective, $2^{\text {nd }}$ ed. Elsevier Science Academic Press: San Diego.

Cumming, D., and Johan, S. (2013). Listing Standards and Fraud, Managerial and Decision Economics 34, 451-470.

Cumming, D., and Walz, U. (2010). Private equity returns and disclosure around the world, Journal of International Business Studies 41, 727-754. 
DeAngelo, L.E. (1988). Managerial competition, information costs, and corporate governance: The use of accounting performance measures in proxy contests, Journal of Accounting and Economics 10, 3-36.

Dechow, P., Sloan, R., and Sweeney, A. (1995). Detecting earnings management, Accounting Review 70, 193-225.

DeFond, M.L., and Jiambalvo, J. (1994). Debt covenant violation and manipulation of accruals, Journal of Accounting and Economics 17, 145-176.

Doidge, C., Karolyi, G.A., and Stulz, R.S. (2016). The U.S. Listing Gap. Journal of Financial Economics, forthcoming.

DuCharme, L.L., Malatesta, P.H., and Sefcik, S.E. (2004). Earnings management, stock issues, and shareholder lawsuits, Journal of Financial Economics 71, 27-49.

Erickson, M., and Wang, S.W. (1999). Earnings management by acquiring firms in stock for stock mergers, Journal of Accounting and Economics 27, 149-176.

Fan, Q. (2007). Earnings management and ownership retention for initial public offering firms: Theory and evidence, Accounting Review 82, 27-64.

Gao, X., Ritter, J.R., and Zhu, Z. (2013). Where have all the IPOs gone? Journal of Financial and Quantitative Analysis 48, 1663-1692.

Garcia-Osma, B., and Young, S. (2009). R\&D expenditure and earnings targets, European Accounting Review 18, 7-32.

Gompers, P. (1995). Optimal investment, monitoring, and the staging of venture capital. Journal of Finance 50, 1461-1490.

Gompers, P., and Lerner, J. (2001). The venture capital revolution, Journal of Economic Perspectives 15, 145-168.

Gorman, M., and Sahlman, W.A. (1989). What do venture capitalists do? Journal of Business Venturing 4, 231-248.

Graham, J.R., Harvey, C.R., and Rajgopal, S. (2005). The economic implications of corporate financial reporting, Journal of Accounting and Economics 40, 3-73.

Grossman, S. J. and Hart, O. (1988) One share - one vote and the market for corporate control, Journal of Financial Economics 20, 175-202.

Healy, Paul M. (1985). The effect of bonus schemes on accounting decisions, Journal of Accounting and Economics 7, 85-107.

Hochberg, Y.V. (2012). Venture capital and corporate governance in the newly public firm, Review of Finance 16, 429-480. 
Hsu, D.H. (2004). What do entrepreneurs pay for venture capital affiliation? Journal of Finance 59, 1805-1844.

Jensen, M. (1993) The modern industrial revolution, exit, and the failure of internal control systems, Journal of Finance 48, 831-880.

Johan, S., and Zhang, M. (2016). Reporting bias in private equity: Reporting frequency, endowments, and governance, TILEC Discussion Paper No. 2014-016. Available at SSRN: http://ssrn.com/abstract=2409903.

Jones, J. (1991). Earnings management during import relief investigations, Journal of Accounting Research 29, 193-228.

Kaplan, S.N., and Strömberg, P.E. (2003). Financial contracting theory meets the real world: Evidence from venture capital contracts, Review of Economic Studies 70, 281-315.

Kaplan, S.N., and Strömberg, P.E. (2004). Characteristics, contracts, and actions: Evidence from venture capitalist analyses, Journal of Finance 59, 2177-2210.

Kasznik, R. (1999). On the Association between Voluntary Disclosure and Earnings Management, Journal of Accounting Research 37, 57-81.

Kortum, S., and Lerner J. (2000). Assessing the contribution of venture capital to innovation, RAND Journal of Economics 31, 674-692.

Kothari, S., Leone, A., and Wasley, C. (2005). Performance Matched Discretionary Accrual Measures, Journal of Accounting and Economics 39, 163-197.

Kothari S.P., Mizik, N., and Roychowdhury, S. (2016). Managing for the Moment: The Role of Earnings Management via Real Activities versus Accruals in SEO Valuation, Accounting Review 91, 559-586.Krishnan, C.N.V., Ivanov V.I., Masulis, R.W., and Singh, A.K. (2011). Venture capital reputation: A survey. The Oxford Handbook of Venture Capital. Oxford University Press, Douglas J. Cumming, ed.

Krishnan, C.N.V., Ivanov, V.I., Masulis, R.W., and Singh, A.K. (2011). Venture capital reputation, post-IPO performance, and corporate governance, Journal of Financial and Quantitative Analysis 46, 1295-1333.

Krishnan, C. N. V., and R. Masulis. "Venture Capital Reputation." In The Oxford Handbook of Venture Capital, ch. 4, D. Cumming, ed. New York: Oxford University Press (2011).

Lee, G., and Masulis, R.W. (2011). Do more reputable financial institutions reduce earnings management by IPO issuers? Journal of Corporate Finance 17, 982-1000.

Lerner, J. (1995). Venture capitalists and the oversight of private firms, Journal of Finance 50, 301-318.

Lo, K. (2008). Earnings management and earnings quality, Journal of Accounting and Economics 45, 350-357. 
Loughran, T., and Ritter, J.R. (2004). Why has IPO underpricing changed over time? Financial Management 33, 5-37.

Masulis, R.W., and Nahata, R. (2009). Financial contracting with strategic investors: Evidence from corporate venture capital backed IPOs, Journal of Financial Intermediation 18, 599-631.

Masulis, R.W., and Nahata, R. (2011). Venture capital conflicts of interest: Evidence from acquisitions of venture-backed firms, Journal of Financial and Quantitative Analysis 46, 395-430.

Morsfield, S.G., and Tan, C.E.L. (2006). Do venture capitalists influence the decision to manage earnings in initial public offerings? Accounting Review 81, 1119-1150.

Nahata, R. (2008). Venture capital reputation and investment performance, Journal of Financial Economics 90, 127-151.

Nahata, R., Hazarika, S., and Tandon, K. (2014). Success in global venture capital investing: Do institutional and cultural differences matter? Journal of Financial and Quantitative Analysis 49, 1039-1070.

Perry, S.E., and Williams, T.H. (1994). Earnings management preceding management buyout offers, Journal of Accounting and Economics 18, 157-179.

Phalippou, L., Rauch, C., and Umber, M.P. (2016). Private Equity Portfolio Company Fees, Available at SSRN: http://ssrn.com/abstract=2702938.

Rangan, S. (1998). Earnings management and the performance of seasoned equity offerings, Journal of Financial Economics 50, 101-122.

Ritter, J.R. (2015). Growth capital-backed IPOs, Financial Review 50, 481-515.

Roychowdhury, S. (2006). Management of earnings through the manipulation of real activities that affect cash flow from operations, Journal of Accounting and Economics 42, 335370 .

Teoh, S.H., Welch, I., and Wong, T.J. (1998a). Earnings management and the long-run market performance of initial public offerings, Journal of Finance 53, 1935-1974.

Teoh, S.H., Welch, I., and Wong, T.J. (1998b). Earnings management and the underperformance of seasoned equity offerings, Journal of Financial Economics 50, 63-99.

Teoh, S.H., Wong, T.J., and Rao, G.R. (1998). Are accruals during initial public offerings opportunistic? Review of Accounting Studies 3, 175-208.Tian, X., Udell, G.F., and Yu, X. (2015). Disciplining delegated monitors: When venture capitalists fail to prevent fraud by their IPO firms, Journal of Accounting and Economics 61, 526-544. 
Tian, X., and Wang, T.Y. (2014). Tolerance for failure and corporate innovation, Review of Financial Studies 27, 211-255.

Walker, M. (2013). How far can we trust earnings numbers? What research tells us about earnings management, Accounting and Business Research 43, 445-481.

Wongsunwai, W. (2013). The effect of external monitoring on accrual based and real earnings management: Evidence from venture backed initial public offerings, Contemporary Accounting Research 30, 296-324.

Zang, A. (2006). Evidence on the tradeoff between real manipulation and accrual manipulation, Working paper, University of Rochester.

Zingales, L. (1995) Insider ownership and the decision to go public, Review of Economic Studies 62, 425-448. 
Table 1. Descriptive statistics

This table gives the descriptive statistics for our 1980-2015 sample. Data on venture capital backing comes from Thomson SDC; financial accounting data comes from Compustat. DA are discretionary accruals calculated as per Jones (1991). REM1 and REM2 are real earnings measured as in Roychowdhury (2006).

\begin{tabular}{|c|c|c|c|c|c|c|}
\hline & $\mathrm{N}$ & Mean & Median & Std. Dev & $\mathrm{P} 25$ & $\mathrm{P} 75$ \\
\hline \multicolumn{7}{|l|}{ Non-VC-backed } \\
\hline DA & 267 & 0.02 & -0.02 & 0.25 & -0.06 & 0.03 \\
\hline REM1 & 267 & 0.57 & 0.16 & 2.46 & -0.10 & 0.89 \\
\hline REM2 & 267 & 0.10 & 0.01 & 2.01 & -0.46 & 0.38 \\
\hline ROA & 267 & 0.03 & 0.06 & 0.23 & -0.00 & 0.12 \\
\hline Leverage & 267 & 0.25 & 0.14 & 0.32 & 0.00 & 0.41 \\
\hline $\mathrm{BM}$ & 267 & 0.53 & 0.38 & 1.61 & 0.24 & 0.60 \\
\hline Size & 267 & 5.78 & 5.82 & 1.52 & 4.63 & 6.91 \\
\hline Sales growth & 267 & 134.27 & 45.38 & 349.06 & 6.30 & 135.23 \\
\hline \multicolumn{7}{|l|}{ VC-backed } \\
\hline DA & 558 & -0.03 & -0.04 & 0.24 & -0.10 & 0.02 \\
\hline REM1 & 558 & 0.09 & -0.04 & 1.45 & -0.49 & 0.47 \\
\hline REM2 & 558 & -0.33 & -0.27 & 1.65 & -1.10 & 0.32 \\
\hline ROA & 558 & -0.09 & 0.03 & 0.86 & -0.09 & 0.10 \\
\hline Leverage & 558 & 0.13 & 0.00 & 0.27 & 0.00 & 0.18 \\
\hline $\mathrm{BM}$ & 558 & 0.39 & 0.30 & 0.38 & 0.17 & 0.49 \\
\hline Size & 558 & 5.28 & 5.16 & 1.13 & 4.63 & 5.88 \\
\hline Sales growth & 558 & 62.86 & 28.21 & 299.39 & 11.15 & 61.63 \\
\hline \multicolumn{7}{|l|}{ Total } \\
\hline DA & 825 & -0.01 & -0.03 & 0.24 & -0.09 & 0.02 \\
\hline REM1 & 825 & 0.25 & 0.05 & 1.85 & -0.38 & 0.57 \\
\hline REM2 & 825 & -0.19 & -0.14 & 1.78 & -0.94 & 0.32 \\
\hline ROA & 825 & -0.05 & 0.04 & 0.72 & -0.06 & 0.10 \\
\hline Leverage & 825 & 0.17 & 0.01 & 0.29 & 0.00 & 0.28 \\
\hline $\mathrm{BM}$ & 825 & 0.44 & 0.33 & 0.97 & 0.19 & 0.53 \\
\hline Size & 825 & 5.44 & 5.33 & 1.29 & 4.63 & 6.26 \\
\hline Sales growth & 825 & 85.97 & 33.05 & 317.87 & 10.01 & 81.07 \\
\hline
\end{tabular}




\section{Table 2. Correlation matrix}

This table gives the Pearson correlations for our variables. $D A$ are discretionary accruals calculated as per Jones (1991). REM1 and REM2 are real earnings measured as in Roychowdhury (2006). Statistical significance is denoted by *,**, and *** at the $10 \%, 5 \%$, and $1 \%$ levels, respectively.

\begin{tabular}{|c|c|c|c|c|c|c|c|c|}
\hline & DA & REM1 & REM2 & ROA & Leverage & $\mathrm{BM}$ & Size & $\begin{array}{l}\text { Sales } \\
\text { growth }\end{array}$ \\
\hline $\mathrm{DA}$ & 1 & & & & & & & \\
\hline REM1 & 0.0134 & 1 & & & & & & \\
\hline REM2 & $0.0765^{*}$ & $0.504^{* * * *}$ & 1 & & & & & \\
\hline ROA & -0.0325 & 0.0492 & $-0.089^{*}$ & 1 & & & & \\
\hline Leverage & -0.0088 & -0.0331 & $0.141^{* * *}$ & $-0.402^{* * *}$ & 1 & & & \\
\hline $\mathrm{BM}$ & -0.0535 & 0.0569 & 0.0488 & $0.0749^{*}$ & $-0.122^{* * *}$ & 1 & & \\
\hline Size & $-0.20^{* * * *}$ & $-0.090^{* *}$ & -0.0276 & $0.381^{* * *}$ & $0.201^{* * *}$ & $0.0708^{*}$ & 1 & \\
\hline Sales growth & 0.0293 & 0.0253 & 0.0584 & 0.0518 & $0.0971^{* *}$ & 0.0221 & $0.319^{* * *}$ & 1 \\
\hline
\end{tabular}




\section{Table 3. VC backing and accrual earnings management}

This table shows results from regressing accrual earnings management on venture capital backing $(V C)$ and our control variables. $D A$ are discretionary accruals calculated as per Jones (1991). REM1 and REM2 are real earnings measured as in Roychowdhury (2006). Model (1) shows results for the three years surrounding the IPO, model (2) shows results for the one year prior to the IPO, model (3) shows results for the one year after the IPO, and model (4) shows results for the two years after the IPO. Industry fixed effects are included, and robust standard errors are in parentheses. Statistical significance is denoted by $* * *$, and $* * *$ at the $10 \%, 5 \%$, and $1 \%$ levels, respectively.

\begin{tabular}{lcccc}
\hline & $(1)$ & $(2)$ & $(3)$ & $(4)$ \\
& DA & DA & DA & DA \\
\hline VC & $-0.038^{* *}$ & $-0.090^{* *}$ & -0.009 & -0.014 \\
& $(0.017)$ & $(0.031)$ & $(0.023)$ & $(0.024)$ \\
ROA & & & & \\
& 0.030 & -0.014 & -0.128 & $0.060^{* *}$ \\
Leverage & $(0.029)$ & $(0.105)$ & $(0.108)$ & $(0.019)$ \\
& 0.023 & -0.007 & -0.003 & 0.125 \\
BM & $(0.066)$ & $(0.059)$ & $(0.077)$ & $(0.082)$ \\
& & & & \\
Size & -0.012 & -0.050 & -0.057 & 0.001 \\
& $(0.010)$ & $(0.079)$ & $(0.036)$ & $(0.005)$ \\
Sales growth & $-0.048^{* *}$ & $-0.096^{* *}$ & -0.015 & -0.024 \\
& $(0.018)$ & $(0.037)$ & $(0.012)$ & $(0.018)$ \\
Constant & $0.000^{*}$ & $0.000^{* *}$ & $0.000^{*}$ & 0.000 \\
& $(0.000)$ & $(0.000)$ & $(0.000)$ & $(0.000)$ \\
\hline$N$ & & & & \\
Adj. $R^{2}$ & $0.382^{* *}$ & $1.029^{* *}$ & 0.087 & 0.165 \\
\hline & $(0.157)$ & $(0.445)$ & $(0.087)$ & $(0.122)$ \\
\hline
\end{tabular}




\section{Table 4. VC backing and real earnings management (REM1)}

This table shows results from regressing real earnings management on venture capital backing $(V C)$ and our control variables. REMI is real earnings measured as in Roychowdhury (2006). Model (1) shows results for the three years surrounding the IPO, model (2) shows results for the one year prior to the IPO, model (3) shows results for the one year after the IPO, and model (4) shows results for the two years after the IPO. Industry fixed effects are included, and robust standard errors are in parentheses. Statistical significance is denoted by *, **, and *** at the $10 \%, 5 \%$, and $1 \%$ levels, respectively.

\begin{tabular}{lcccc}
\hline & $(1)$ & $(2)$ & $(3)$ & $(4)$ \\
& REM1 & REM1 & REM1 & REM1 \\
\hline VC & $-0.702^{* * *}$ & $-0.669^{* * *}$ & $-0.574^{* * *}$ & $-0.712^{* * *}$ \\
& $(0.067)$ & $(0.182)$ & $(0.128)$ & $(0.149)$ \\
ROA & & & & \\
& 0.268 & 0.525 & $1.304^{* * *}$ & 0.119 \\
Leverage & $(0.202)$ & $(0.511)$ & $(0.315)$ & $(0.195)$ \\
& -0.049 & 0.414 & 0.054 & -0.184 \\
BM & $(0.308)$ & $(0.878)$ & $(0.245)$ & $(0.666)$ \\
& & & & \\
Size & 0.036 & 0.368 & 0.321 & 0.014 \\
& $(0.040)$ & $(0.286)$ & $(0.185)$ & $(0.036)$ \\
Sales growth & $0.095^{*}$ & 0.031 & -0.043 & 0.053 \\
& $(0.052)$ & $(0.175)$ & $(0.080)$ & $(0.120)$ \\
Constant & $\left(0.000^{* * *}\right.$ & $0.001^{* * *}$ & $0.001^{* *}$ & 0.000 \\
& & $(0.000)$ & $(0.000)$ & $(0.000)$ \\
\hline$N$ & & & & \\
Adj. $R^{2}$ & $(0.349)$ & $(1.303)$ & $(0.595)$ & $(0.737)$ \\
\hline
\end{tabular}




\section{Table 5. VC backing and real earnings management (REM2)}

This table shows results from regressing real earnings management on venture capital backing $(V C)$ and our control variables. REM2 is real earnings measured as in Roychowdhury (2006). Model (1) shows results for the three years surrounding the IPO, model (2) shows results for the one year prior to the IPO, model (3) shows results for the one year after the IPO, and model (4) shows results for the two years after the IPO. Industry fixed effects are included, and robust standard errors are in parentheses. Statistical significance is denoted by *, **, and *** at the $10 \%, 5 \%$, and $1 \%$ levels, respectively.

\begin{tabular}{|c|c|c|c|c|}
\hline & $\begin{array}{c}(1) \\
\text { REM2 }\end{array}$ & $\begin{array}{c}(2) \\
\text { REM2 }\end{array}$ & $\begin{array}{c}(3) \\
\text { REM2 }\end{array}$ & $\begin{array}{c}(4) \\
\text { REM2 }\end{array}$ \\
\hline $\mathrm{VC}$ & $\begin{array}{c}-0.296^{* * *} \\
(0.079)\end{array}$ & $\begin{array}{c}-0.421^{* *} \\
(0.157)\end{array}$ & $\begin{array}{l}-0.207 \\
(0.118)\end{array}$ & $\begin{array}{l}-0.215 \\
(0.179)\end{array}$ \\
\hline ROA & $\begin{array}{l}-0.040 \\
(0.072)\end{array}$ & $\begin{array}{l}-0.144 \\
(0.208)\end{array}$ & $\begin{array}{c}0.373 \\
(0.330)\end{array}$ & $\begin{array}{c}0.032 \\
(0.107)\end{array}$ \\
\hline Leverage & $\begin{array}{c}0.066 \\
(0.169)\end{array}$ & $\begin{array}{c}0.282 \\
(0.488)\end{array}$ & $\begin{array}{c}0.080 \\
(0.232)\end{array}$ & $\begin{array}{c}0.266 \\
(0.418)\end{array}$ \\
\hline $\mathrm{BM}$ & $\begin{array}{c}0.042 \\
(0.046)\end{array}$ & $\begin{array}{c}0.698^{* * *} \\
(0.164)\end{array}$ & $\begin{array}{c}0.258 \\
(0.203)\end{array}$ & $\begin{array}{c}0.006 \\
(0.036)\end{array}$ \\
\hline Size & $\begin{array}{l}0.113^{* * *} \\
(0.047)\end{array}$ & $\begin{array}{c}0.236^{*} \\
(0.117)\end{array}$ & $\begin{array}{c}0.024 \\
(0.034)\end{array}$ & $\begin{array}{l}-0.022 \\
(0.062)\end{array}$ \\
\hline Sales growth & $\begin{array}{c}0.000 \\
(0.000)\end{array}$ & $\begin{array}{c}-0.001^{* *} \\
(0.000)\end{array}$ & $\begin{array}{c}0.000 \\
(0.000)\end{array}$ & $\begin{array}{c}0.000^{* * * *} \\
(0.000)\end{array}$ \\
\hline Constant & $\begin{array}{c}-2.639^{* * * *} \\
(0.355)\end{array}$ & $\begin{array}{c}-5.282^{* * * *} \\
(1.024)\end{array}$ & $\begin{array}{c}-2.049^{* * *} \\
(0.297)\end{array}$ & $\begin{array}{r}-1.551^{* * * *} \\
(0.392)\end{array}$ \\
\hline $\begin{array}{l}N \\
\text { Adj. } R^{2}\end{array}$ & $\begin{array}{c}825 \\
0.728\end{array}$ & $\begin{array}{c}275 \\
0.745\end{array}$ & $\begin{array}{c}275 \\
0.749\end{array}$ & $\begin{array}{c}275 \\
0.739\end{array}$ \\
\hline
\end{tabular}

